Article

\title{
A Novel Fungal Metabolite with Beneficial Properties for Agricultural Applications
}

Francesco Vinale ${ }^{1, \dagger, *}$, Gelsomina Manganiello ${ }^{2, \dagger}$, Marco Nigro ${ }^{2}$, Pierluigi Mazzei ${ }^{3}$, Alessandro Piccolo ${ }^{3}$, Alberto Pascale ${ }^{2}$, Michelina Ruocco ${ }^{1}$, Roberta Marra ${ }^{1,2}$, Nadia Lombardi ${ }^{2}$, Stefania Lanzuise ${ }^{2}$, Rosaria Varlese ${ }^{2}$, Pierpaolo Cavallo ${ }^{4}$, Matteo Lorito ${ }^{1,2}$ and Sheridan L. Woo ${ }^{1,2}$

1 Istituto per la Protezione Sostenibile delle Piante, Consiglio Nazionale delle Ricerche, via Università 133, 80055 Portici, Italy

2 Dipartimento di Agraria, Università di Napoli 'Federico II', Portici, 80055 Naples, Italy

3 Centro Interdipartimentale di Spettroscopia di Risonanza Magnetica Nucleare (CERMANU), Università degli Studi di Napoli 'Federico II', Portici, 80055 Naples, Italy

4 Dipartimento di Fisica, Università di Salerno, Via Giovanni Paolo II, 132, 84084 Fisciano, Italy

$\dagger$ These authors contributed equally to this work.

* Author to whom correspondence should be addressed; E-Mail: f.vinale@ipp.cnr.it; Tel.: +39-081-253-9338; Fax: +39-081-253-9339.

Received: 5 March 2014; in revised form: 26 June 2014 / Accepted: 1 July 2014 / Published: 8 July 2014

Abstract: Trichoderma are ubiquitous soil fungi that include species widely used as biocontrol agents in agriculture. Many isolates are known to secrete several secondary metabolites with different biological activities towards plants and other microbes. Harzianic acid (HA) is a T. harzianum metabolite able to promote plant growth and strongly bind iron. In this work, we isolated from the culture filtrate of a T. harzianum strain a new metabolite, named isoharzianic acid (iso-HA), a stereoisomer of HA. The structure and absolute configuration of this compound has been determined by spectroscopic methods, including UV-Vis, MS, 1D and 2D NMR analyses. In vitro applications of iso-HA inhibited the mycelium radial growth of Sclerotinia sclerotiorum and Rhizoctonia solani. Moreover, iso HA improved the germination of tomato seeds and induced disease resistance. HPLC-DAD experiments showed that the production of HA and iso HA was affected by the presence of plant tissue in the liquid medium. In particular, tomato tissue elicited the production of HA but negatively modulated the biosynthesis of its analogue 
iso-HA, suggesting that different forms of the same Trichoderma secondary metabolite have specific roles in the molecular mechanism regulating the Trichoderma plant interaction.

Keywords: Trichoderma; secondary metabolites; isoharzianic acid; harzianic acid; plant growth promotion; disease resistance

\section{Introduction}

The use of microbes for pest management in agriculture is one of the most effective biological control strategies. The beneficial effects are strain dependent and the advantages for the associated plant include the suppression of pathogens by using a variety of mechanisms (i.e., antibiosis, parasitism, competition for nutrients, etc.), the promotion of plant growth and the improvement of host resistance to both biotic and abiotic stresses [1-3].

Secondary metabolites are chemically different natural compounds of relatively low molecular weight (in most cases $<3 \mathrm{kDa}$ ), that are mainly produced by microorganisms and plants, and typically associated to individual genera, species or strains. They are biosynthesized along specialized pathways from primary metabolites, exhibit a wide range of biological activities and play an important role in regulating interactions between organisms [4]. Included in this group are antibiotics, which are natural products capable of inhibiting or killing microbial competitors $[5,6]$.

In fungi, the production of secondary metabolites has been often correlated to specific stages of morphological differentiation, and associated to the phase of active growth [7]. Interestingly, some fungal secondary metabolites can modify the growth and the metabolism of plants, while others seem to target specific fungal processes such as sporulation and hyphal elongation [7]. Thus, the expression of secondary metabolites may occur at a predictable point during the normal life cycle of some fungi, including those used for agriculture applications [7].

Some fungi of the genus Trichoderma may act as symbionts of plants, and are presently marketed as biopesticides and biofertilizers due to their ability to protect crops and promote vegetative growth [1-3]. These microbes are well known producers of secondary metabolites with different biological activities [8-10]. The production of such compounds varies according to the strain and in relation to the equilibrium between elicited biosynthesis and biotransformation rates (or degradation by other microbes) [11].

In this work we report the isolation and the characterization of a new metabolite named isoharzianic acid (iso-HA), a stereoisomer of harzianic acid, from the culture filtrate of a T. harzianum strain isolated from decomposing hardwood bark. The biological activity of this metabolite was investigated both in vitro against the fungal pathogens Sclerotinia sclerotiorum and Rhizoctonia solani and in vivo in terms of plant growth promotion and induction of disease resistance. Moreover, the influence of plant tissue on the production of HA and iso-HA has been also examined. 


\section{Results and Discussion}

T. harzianum culture filtrate was extracted exhaustively with ethyl acetate to give a red-brown residue from which HA (1) and iso-HA (2) (Figure 1) were isolated after RP-18 vacuum chromatography or semi-preparative HPLC (Figure 2). The structure of $\mathbf{1}$ was determined by comparison of its NMR spectroscopic data with those of an authentic standard [12,13]. The absolute configuration of $\mathbf{1}$, determined by X-ray diffraction studies, its antibiotic activity and plant growth promotion effect have been reported in a previous study [13]. Recently, we demonstrated the ability of this tetramic acid to bind with a good affinity essential metals such as $\mathrm{Fe}^{3+}$, thus representing a previously unrecognized siderophore [14].

Figure 1. Chemical structures of (1) HA; (2) iso-HA.

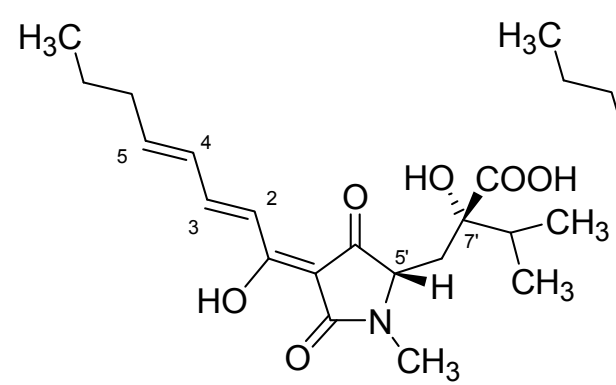

1<smiles>C/C=C/C(O)=C1C(=O)[C@H](CC(O)(C(=O)O)C(C)C)N(C)C1=O</smiles>

2

Figure 2. Chromatogram of T. harzianum extract, as monitored by HPLC-DAD at $360 \mathrm{~nm}$ (10 to $20 \mathrm{~min})$.

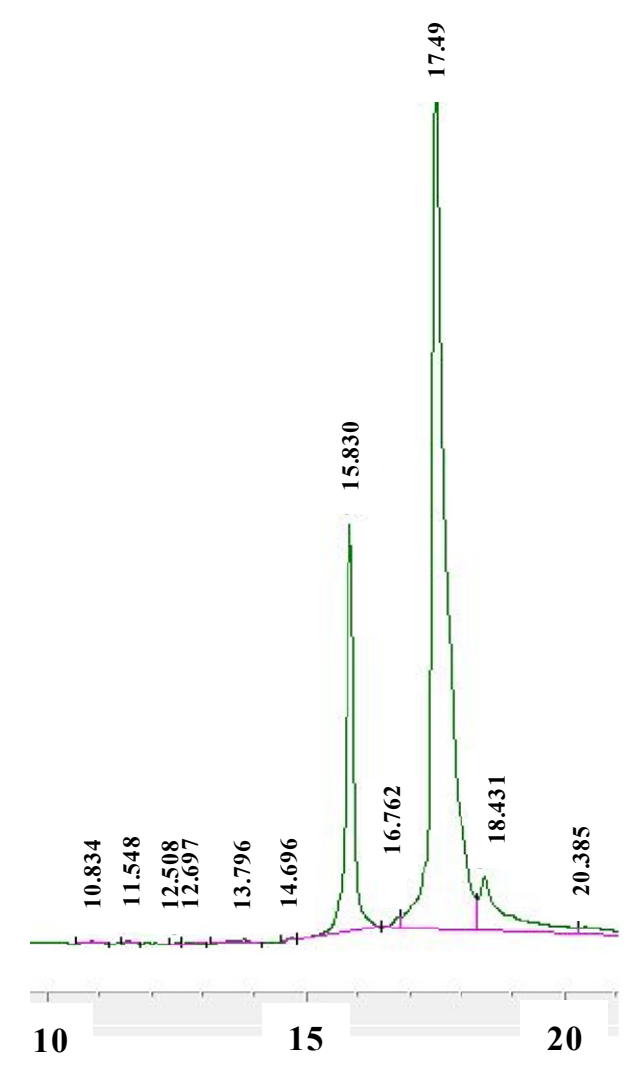


iso-HA was obtained as a yellow solid and its ESI-MS/MS spectrum showed a molecular ion peak at $366.1909 \mathrm{~m} / z$ corresponding to $\mathrm{C}_{19} \mathrm{H}_{27} \mathrm{NO}_{6}$. HA (1) and iso-HA (2) had similar mass spectra with molecular ions at $m / z 366\left([\mathrm{M}+\mathrm{H}]^{+}\right)$and main fragments at $m / z 320\left(\left[\mathrm{M}+\mathrm{H}-\mathrm{HCO}_{2} \mathrm{H}\right]^{+}\right), 224$ and 138 . Interestingly, HA showed an extra peak at $348 \mathrm{~m} / z\left(\left[\mathrm{M}+\mathrm{H}-\mathrm{H}_{2} \mathrm{O}\right]^{+}\right)$. The optical rotation of iso-HA is $[\alpha]_{\mathrm{D}}-15(\mathrm{c} 1.1, \mathrm{MeOH})$, while is $[\alpha]_{\mathrm{D}}+16(\mathrm{c} 1.06, \mathrm{MeOH})$ for HA [12].

The ${ }^{1} \mathrm{H}$ - and ${ }^{13} \mathrm{C}$-NMR spectra of these two compounds (Table 1) showed high similarities. The analyses of mono- and bidimensional NMR spectra showed that these two metabolites have the same signals except H-5' and H-6', suggesting a different stereochemistry of C5 and C6. NOESY experiments were performed to confirm this hypothesis and allowed to determine the configuration of the two stereoisomers. In particular, NOESY experiments revealed, in case of HA, a through-space correlation between the H-5' and H-6' b protons, which, conversely, was not detected in case of iso-HA. However, no other different correlations between HA and iso-HA were observed, thus suggesting the different orientation of $\mathrm{H}-5$ '.

Table 1. ${ }^{1} \mathrm{H}$ - and ${ }^{13} \mathrm{C}-\mathrm{NMR}$ spectral data of $\mathrm{HA}$ and iso-HA (in $\mathrm{CD}_{3} \mathrm{OD}$ ).

\begin{tabular}{|c|c|c|c|c|c|c|c|c|}
\hline \multirow{2}{*}{ Position } & \multicolumn{4}{|c|}{ HA (1) } & \multicolumn{4}{|c|}{ iso-HA (2) } \\
\hline & $\delta^{13} \mathrm{C}$ & $\delta^{1} \mathbf{H}$ & Multi & $\mathrm{J}(\mathrm{Hz})$ & $\delta^{13} \mathrm{C}$ & $\delta{ }^{1} \mathbf{H}$ & Multi & $\mathrm{J}(\mathrm{Hz})$ \\
\hline 1 & 174.0 & - & & & 174.0 & 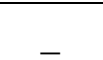 & & \\
\hline 2 & 119.3 & 7.0 & $\mathrm{~d}$ & 15.6 & 119.4 & 7.05 & $\mathrm{~d}$ & 15.25 \\
\hline 3 & 146.2 & 7.57 & $\mathrm{~m}$ & - & 146.2 & 7.47 & $\mathrm{dd}$ & $10.17 ; 5.4$ \\
\hline 4 & 129.7 & 6.35 & $\mathrm{~m}$ & _- & 129.7 & 6.35 & $\mathrm{~m}$ & _- \\
\hline 5 & 148.5 & 6.30 & $\mathrm{~m}$ & - & 148.5 & 6.30 & $\mathrm{~m}$ & - \\
\hline 6 & 35.4 & 2.19 & $\mathrm{~m}$ & - & 35.4 & 2.19 & $\mathrm{~m}$ & - \\
\hline 7 & 21.8 & 1.50 & $\mathrm{~m}$ & - & 21.8 & 1.50 & $\mathrm{~m}$ & - \\
\hline 8 & 13.7 & 0.93 & $\mathrm{~m}$ & - & 13.7 & 0.93 & $\mathrm{~m}$ & - \\
\hline $2^{\prime}$ & 174.0 & - & & - & 174.0 & - & & - \\
\hline $3^{\prime}$ & 99.6 & - & $\mathrm{q}$ & - & 99.5 & - & $\mathrm{q}$ & - \\
\hline $4^{\prime}$ & 195.0 & _- & & - & 195.1 & _- & & _- \\
\hline $5^{\prime}$ & 63.7 & 3.62 & dd & $1.17,9.3$ & 63.6 & 3.80 & $\mathrm{dd}$ & $2.7,4.6$ \\
\hline 6'a & 34.9 & 2.20 & $\mathrm{dd}$ & & 34.8 & 2.2 & $\mathrm{c}$ & \\
\hline $6^{\prime} b$ & & 2.51 & & & & 2.2 & & \\
\hline $7^{\prime}$ & 78.1 & - & $q$ & - & 78.0 & - & $q$ & _ \\
\hline $8^{\prime}$ & 35.9 & 2.02 & $\mathrm{~m}$ & - & 35.8 & 2.02 & $\mathrm{~m}$ & - \\
\hline $9^{\prime}$ & 17.2 & 0.98 & $\mathrm{~m}$ & - & 17.2 & 0.98 & $\mathrm{~m}$ & - \\
\hline $10^{\prime}$ & 16.4 & 0.99 & $\mathrm{~m}$ & - & 16.4 & 0.99 & $\mathrm{~m}$ & - \\
\hline $11^{\prime}$ & 27.4 & 2.99 & $\mathrm{~s}$ & _- & 27.3 & 2.98 & $\mathrm{~s}$ & - \\
\hline $12^{\prime}$ & 176.8 & & & & 176.7 & & & \\
\hline
\end{tabular}

c: Overlapping NMR signals. Abbreviation, s: singlet, d: doublet, dd: doublet of doublets, m: multiplet, q: quartet.

All these data implies that the metabolite 2-hydroxy-2-[4-(1-hydroxyocta-2,4-dienylidene)-1methyl-3,5-dioxopyrrolidin-2-ylmethyl]-3-methylbutyric acid named iso-HA is a diastereoisomer of HA with the stereochemistry reported in Figure 1. The difference between these two tetramic acids determines their different chemical and physical characteristics (UV $\lambda_{\max } n m(\log \varepsilon) \mathrm{HA}=344$ (3.11), iso $\mathrm{HA}=340$ (4.04), different solubility in organic solvents). 
In vitro assays were performed to assess the iso-HA antibiotic activity. This compound, at concentration of $10^{-3} \mathrm{M}$, inhibited the growth of the phytopathogenic agents $R$. solani and S. sclerotiorum of about $40 \%$ and $20 \%$, respectively, while at concentrations of $10^{-4} \mathrm{M}$ and $10^{-5} \mathrm{M}$ it showed lower effects compared to untreated control (Figure 3). No significant growth inhibitions were observed with other two fungal pathogens, Botrytis cinerea and Phytium ultimum (data not shown).

Figure 3. Antibiotic activity of iso-HA at different concentrations on Rhizoctonia solani (Rhizoctonia -n-) and Sclerotinia sclerotiorum (Scletotinia - $\$$-). \% Inhibition of radial growth.

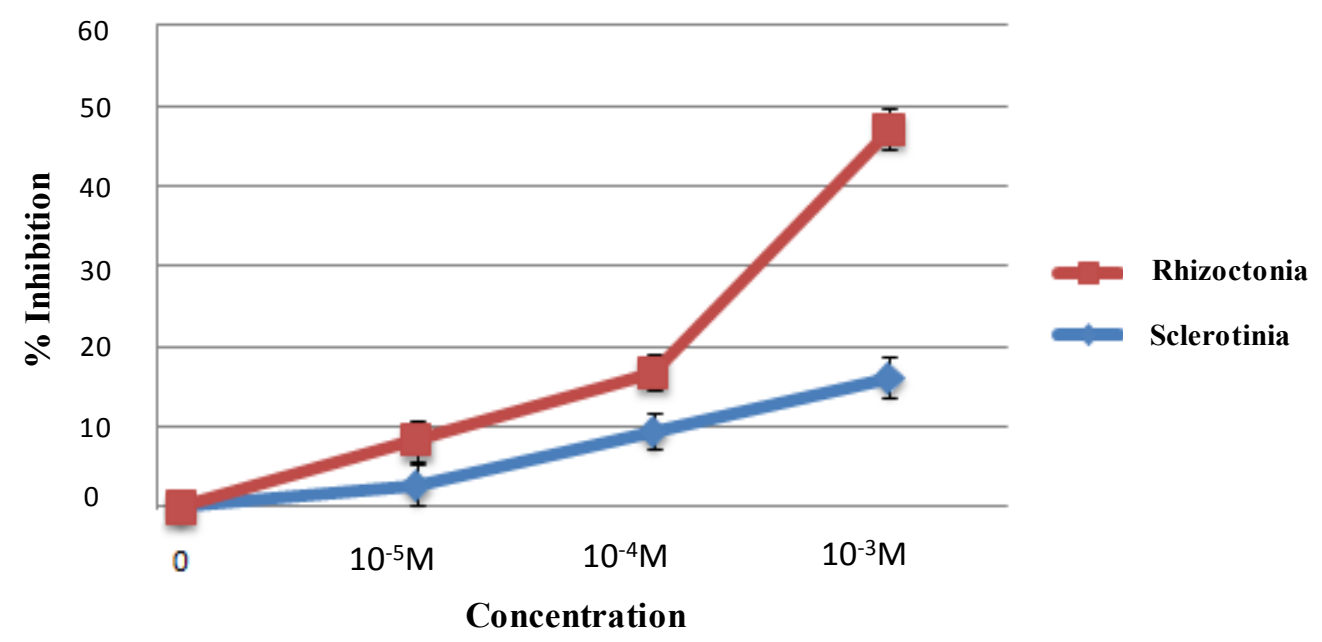

The in vitro effect of iso-HA and HA on tomato growth was evaluated in terms of seed germination, stem and root lengths (Figure 4). Both metabolites promoted seed germination (Table 2) and plant growth, with an increase of $35 \%$ in stem length (iso-HA and $\mathrm{HA} 10^{-7} \mathrm{M}$ ) and of $65 \%$ in root length (iso-HA and HA $10^{-7} \mathrm{M}$ ). Interestingly, iso-HA enhanced the plant fresh weight at $10^{-6}$ and $10^{-7} \mathrm{M}$, while small differences were observed with HA treatments.

Figure 4. In vitro plant growth promotion effects of iso-HA $\left(10^{-5}, 10^{-6}, 10^{-7}, 10^{-8}\right.$ and $10^{-9}$ M) on tomato seedlings. (a) Stem and (b) root lengths. Values indicates the \% increase of growth as compared to untreated control plants. Each bar is the mean \pm the standard deviation.

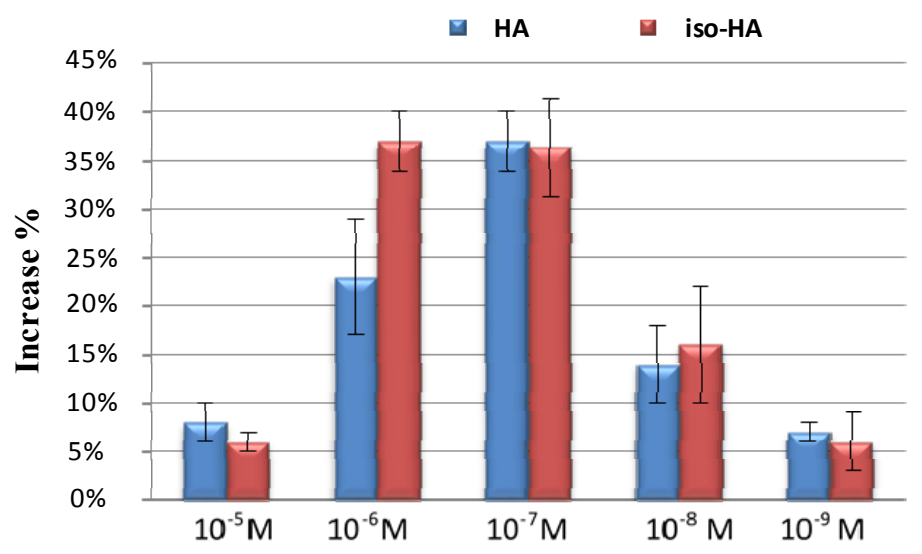

(a) 
Figure 4. Cont.

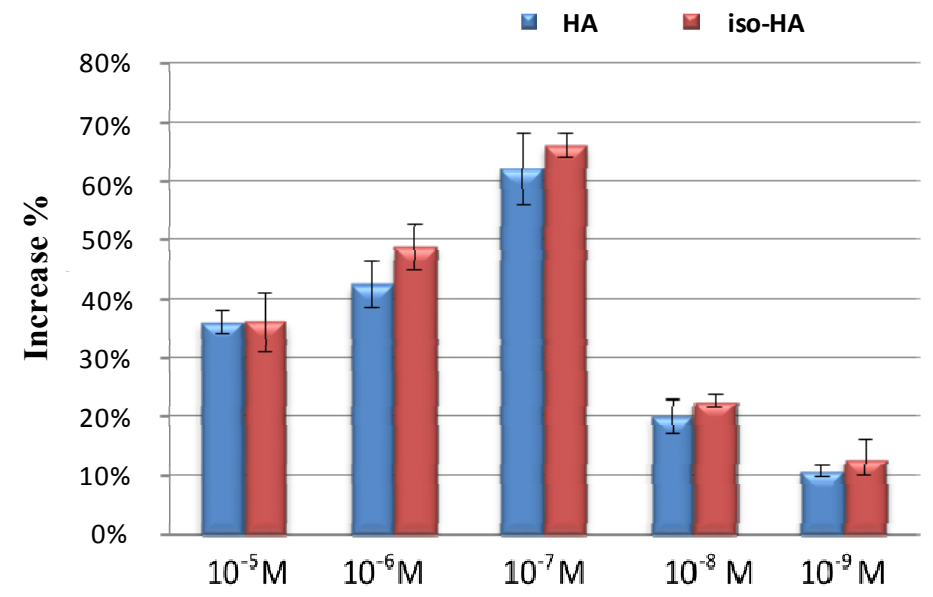

(b)

Table 2. In vitro effect of iso-HA and HA on tomato seed germination $(12,24,36,48 \mathrm{~h}$ after sowing). $\mathrm{DS}=$ standard deviation.

\begin{tabular}{ccccccccc}
\hline & \multicolumn{7}{c}{ \% of Germination } \\
\hline Treatment & $\mathbf{1 2}$ h & DS & $\mathbf{2 4} \mathbf{h}$ & DS & $\mathbf{3 6}$ h & DS & $\mathbf{4 8 ~ h}$ & DS \\
\hline Control & $0 \%$ & $0 \%$ & $0 \%$ & $0 \%$ & $55 \%$ & $3.6 \%$ & $100 \%$ & $0 \%$ \\
HA $10^{-5} \mathrm{M}$ & $0 \%$ & $0 \%$ & $50 \%$ & $3.9 \%$ & $100 \%$ & $0 \%$ & $100 \%$ & $0 \%$ \\
HA $10^{-6} \mathrm{M}$ & $0 \%$ & $0 \%$ & $72 \%$ & $4.1 \%$ & $88 \%$ & $3.4 \%$ & $100 \%$ & $0 \%$ \\
$\mathrm{HA} 10^{-7} \mathrm{M}$ & $0 \%$ & $0 \%$ & $55 \%$ & $3.1 \%$ & $100 \%$ & $0 \%$ & $100 \%$ & $0 \%$ \\
$\mathrm{HA} 10^{-8} \mathrm{M}$ & $0 \%$ & $0 \%$ & $61 \%$ & $7.3 \%$ & $76 \%$ & $12.3 \%$ & $100 \%$ & $0 \%$ \\
$\mathrm{HA} 10^{-9} \mathrm{M}$ & $0 \%$ & $0 \%$ & $56 \%$ & $7.9 \%$ & $63 \%$ & $11.1 \%$ & $100 \%$ & $0 \%$ \\
iso-HA $10^{-5} \mathrm{M}$ & $0 \%$ & $0 \%$ & $72 \%$ & $3.9 \%$ & $100 \%$ & $0 \%$ & $100 \%$ & $0 \%$ \\
iso-HA $10^{-6} \mathrm{M}$ & $0 \%$ & $0 \%$ & $66 \%$ & $5.2 \%$ & $100 \%$ & $0 \%$ & $100 \%$ & $0 \%$ \\
iso-HA $10^{-7} \mathrm{M}$ & $0 \%$ & $0 \%$ & $88 \%$ & $5.6 \%$ & $100 \%$ & $0 \%$ & $100 \%$ & $0 \%$ \\
iso-HA $10^{-8} \mathrm{M}$ & $0 \%$ & $0 \%$ & $62 \%$ & $2.6 \%$ & $83 \%$ & $11.8 \%$ & $100 \%$ & $0 \%$ \\
iso-HA $10^{-9} \mathrm{M}$ & $0 \%$ & $0 \%$ & $56 \%$ & $2.8 \%$ & $67 \%$ & $3.8 \%$ & $100 \%$ & $0 \%$ \\
\hline
\end{tabular}

In vivo treatment of tomato plants with iso-HA increased stem length by $22 \%, 35 \%$ and $19 \%$ at concentrations of $10^{-5}, 10^{-6}, 10^{-7} \mathrm{M}$, respectively, compared to untreated control (Figure 5). Moreover, the ability of iso-HA to induce systemic resistance against $B$. cinerea was evaluated. A reduction of the necrotic area $(90 \%)$ caused by the pathogen was observed $48 \mathrm{~h}$ after a drench application of iso-HA at $10^{-5} \mathrm{M}$ (Figure 6).

Some Trichoderma strains produce compounds that can cause substantial changes in the metabolism of the host plant [10,15]. The involvement of secondary metabolites in the ability of Trichoderma spp. to activate plant defence mechanisms and regulate plant growth has been investigated $[16,17]$. HA is a natural product that demonstrates antifungal and plant growth promoting activities [13]. In this paper we indicate that iso-HA is an antifungal compound and also an inducer of plant disease resistance. 
Figure 5. In vivo plant growth promotion effects of iso-HA on tomato. (Left) untreated control; (Right) plant treated with iso-HA $10^{-6} \mathrm{M}$.
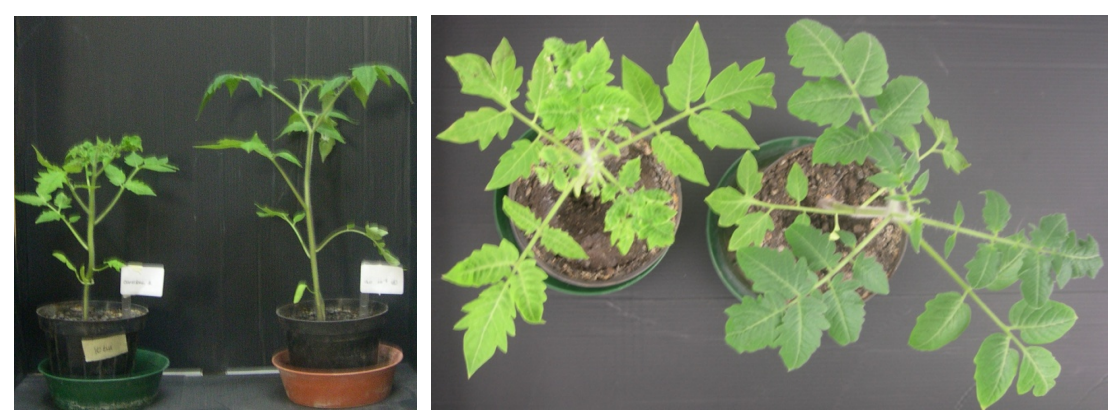

Figure 6. Induction of disease resistance against $B$. cinerea. Plants were drenched with iso-HA at different concentrations $\left(10^{-5}, 10^{-6}, 10^{-7} \mathrm{M}\right)$. Each bar is the mean \pm the standard deviation. Treatments with the same letter are not significantly different $(p<0.05)$.

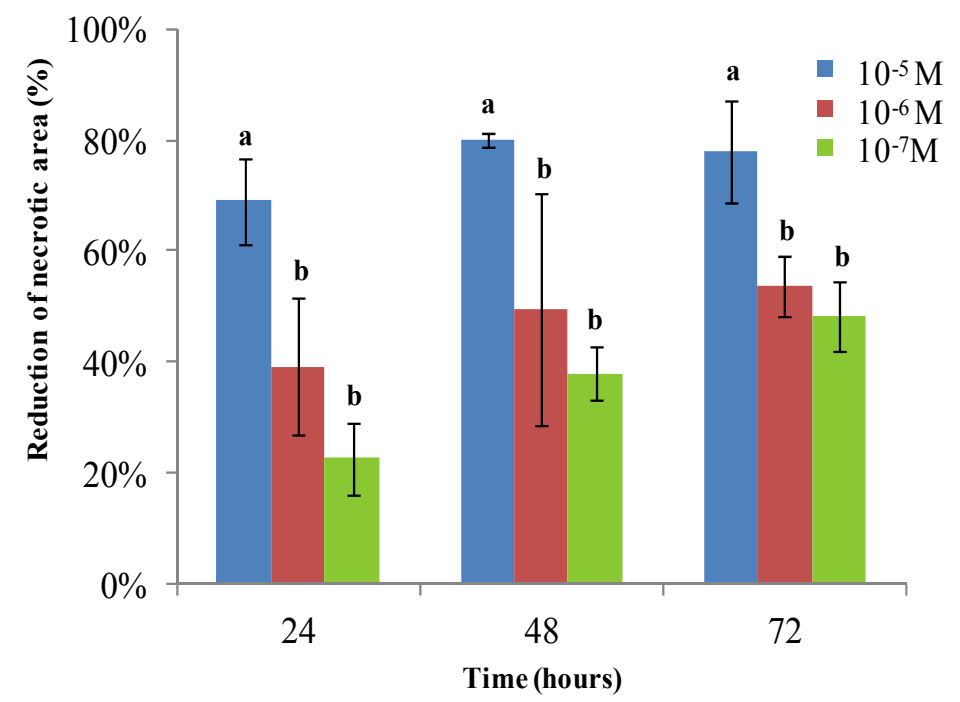

In order to test if the presence of plant may influence the production of HA and iso-HA in T. harzianum, tomato tissue was added to the cultivation media (PDB, PDB 1/5 strength and SM) in order to mimic the composition of a natural substrate or a naturally occurring plant-microbe interaction. The presence of tomato plant modulated the production of the tetramic acid derivatives as reported in Figure 7. For both metabolites, the production was significantly higher in potato dextrose broth (PDB - full and 1/5 strength) compared to the salt medium. The biosynthesis of HA was elicited by tomato tissue in PDB (both full and 1/5 strength). On the contrary, this was not observed for iso HA, whose accumulation was reduced by the presence of plant tissue added in the cultivation substrate. However no significant differences were observed in salt medium amended or not with tomato tissue (data not shown). Moreover, HA and iso-HA were not detected in the mycelium extracts (data not shown).

Interestingly, the dual culture of $T$. harzianum and calli of Catharathus roseus produced another tetramic acid compound named trichosedin ( 3 in Figure 8), that was not produced in the single culture of $T$. harzianum or C. roseus callus [18]. This fungal metabolite affects the root and shoot growth of several plant species [19]. Dual cultures of a fungus and a plant provide a simple method of 
establishing plant-fungus interaction and allow isolation of metabolites induced by one of the system components. Previous studies also demonstrated that the production of secondary metabolites was induced by fungal cell wall material or by the presence of pathogens [11].

Figure 7. Production of HA (a) and iso-HA (b) in different media amended with tomato plant tissue. PDB = full PDB (- $\downarrow$ ); PDB 1/5 = 1/5 strength PDB (- $\mathbf{\Delta}$-); PDB + plant tissue $=$ full PDB amended with tomato plant tissue (-n-); PDB $1 / 5+$ plant tissue $=1 / 5$ strength PDB emended with tomato plant tissue (-x-); SM = salt medium with $1 \%$ glucose $(-\bullet-)$. Each point on the line is the mean \pm the standard deviation of four independent biological replicates. Point on the line with the same letter are not significantly different; point on the line without the letter are significantly different $(p<0.05)$.

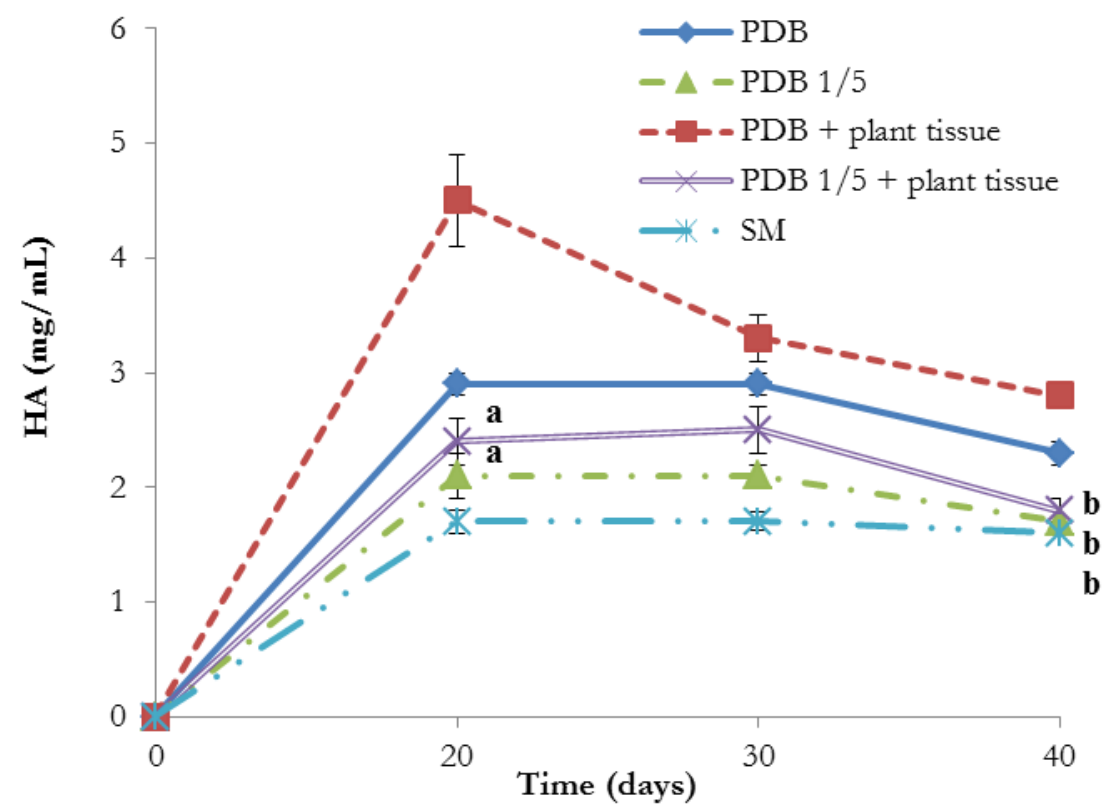

(a)

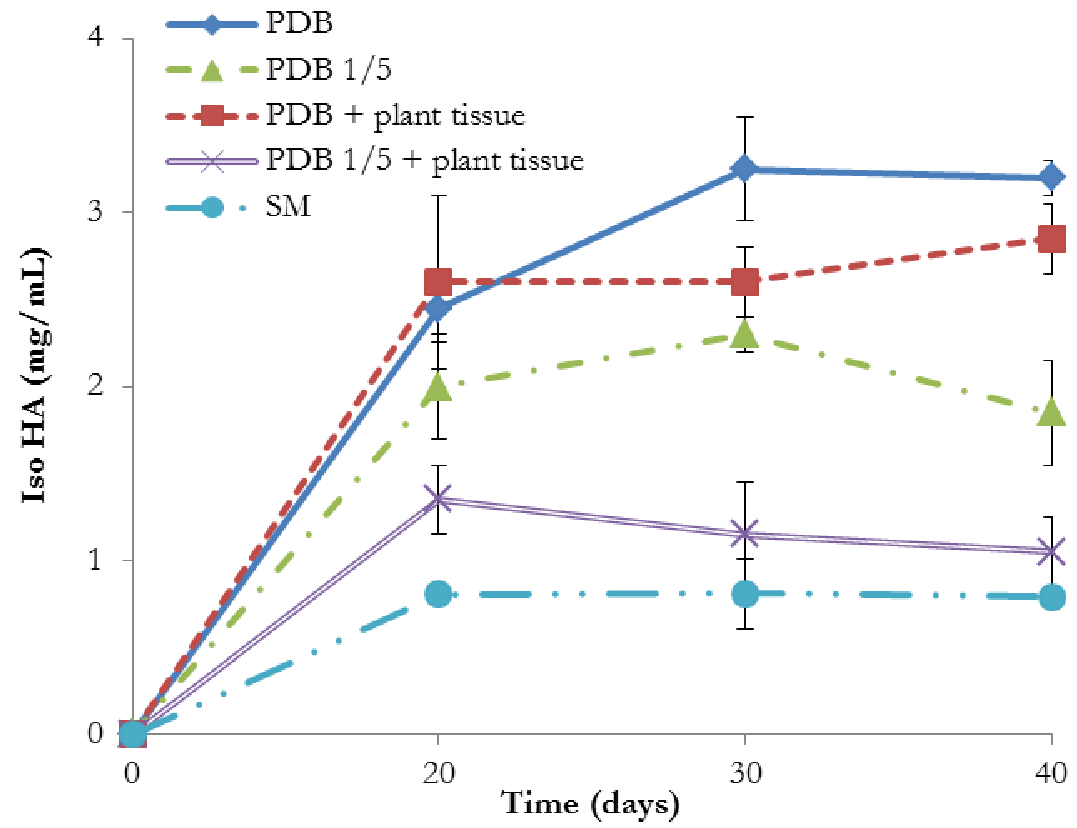

(b) 
Figure 8. Chemical structure of trichosedin (3).

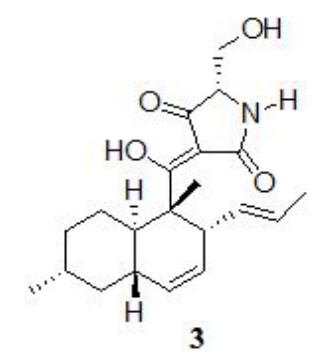

\section{Experimental Section}

\subsection{General Information}

Chromatographic separation was performed using an HPLC (1260 Infinity; Agilent Technologies, Santa Clara, CA, USA) equipped with a Diode Array Detector (DAD) and a Zorbax Eclipse Plus C18 $3.5 \mu \mathrm{m}$ column $(100 \times 4.6 \mathrm{~mm}$-Agilent $)$. The eluents were: $\mathbf{A}=$ water $+0.1 \%$ formic acid, and $\mathbf{B}=$ acetonitrile. The gradient program was as follows: $10 \%-100 \% \mathrm{~B}(18 \mathrm{~min}), 100 \% \mathrm{~B}(16 \mathrm{~min})$ at a constant flow of $0.5 \mathrm{~mL} \mathrm{~min}^{-1}$ (injection volume: $\left.20 \mu \mathrm{L}\right)$. A Prodigy $10 \mu \mathrm{m}$ ODS column $(250 \times 10 \mathrm{~mm}$, Phenomenex Torrance, CA, USA) was used for semi-preparative HPLC (gradient program as reported above at a constant flow of $3 \mathrm{~mL} \mathrm{~min}{ }^{-1}$, injection volume: $500 \mu \mathrm{L}$ ). ${ }^{1} \mathrm{H}$ and ${ }^{13} \mathrm{C}$-NMR spectra were recorded with a Bruker Avance 400 instrument (Bruker Biospin, Rheinstetten, Germany) operating at $400\left({ }^{1} \mathrm{H}\right)$ and $100\left({ }^{13} \mathrm{C}\right) \mathrm{MHz}$, using residual and deuterated solvent peaks as reference standards. Electrospray mass spectra were recorded on a Agilent LCMS QTOF 6540 (Agilent Technologies, Santa Clara, CA, USA).

\subsection{Fungal Strains}

The phytopathogens R. solani, S. sclerotiorum, P. ultimum and Botrytis cinerea, as well as the antagonistic fungus, T. harzianum strain M10 were maintained on potato dextrose agar (PDA, Sigma, St Louis, MO, USA) at room temperature and sub-cultured bimonthly. Two 7-mm diameter plugs of T. harzianum, obtained from actively growing margins of PDA cultures, were inoculated into conical flasks containing $1.5 \mathrm{~L}$ of sterile potato dextrose broth (PDB). The stationary cultures were incubated for 30 days at $25^{\circ} \mathrm{C}$.

\subsection{Production and Isolation of Trichoderma Secondary Metabolites}

The cultures of $T$. harzianum strain M10 were filtered under vacuum through filter paper (No. 4, Whatman, Brentford, UK), and the filtrates stored at $2{ }^{\circ} \mathrm{C}$ for $24 \mathrm{~h}$. The filtered culture broth (2 L) was acidified to $\mathrm{pH} 4$ with $5 \mathrm{M} \mathrm{HCl}$ and extracted exhaustively with ethyl acetate (EtOAc). The combined organic fraction was dried $\left(\mathrm{Na}_{2} \mathrm{SO}_{4}\right)$ and evaporated in vacuo at $35{ }^{\circ} \mathrm{C}$. The red residue recovered was dissolved in $\mathrm{CHCl}_{3}$ and extracted three times with $2 \mathrm{M} \mathrm{NaOH}$. Harzianic acid (HA) and isoharzianic acid (iso-HA) were then precipitated with $2 \mathrm{M} \mathrm{HCl}$. The solid phase was recovered (135 $\mathrm{mg}$ ), solubilised and subjected to RP-18 vacuum chromatography $(20 \mathrm{~g})$, eluting with a gradient of methanol $(\mathrm{MeOH}): \mathrm{H}_{2} \mathrm{O}: \mathrm{CH}_{3} \mathrm{CN}$ (1:8:1 to 10:0:0), or semi-preparative HPLC (see "Production of HA and iso-HA 
in the presence of plant tissue" section). After the separation, $45 \mathrm{mg}$ of pure HA and $30 \mathrm{mg}$ of iso-HA were collected. The homogeneity of pure pooled products was verified by analytical reverse-phase TLC (glass pre-coated Silica gel 60 RP-18 plates-Merck Kieselgel 60 TLC Silica gel 60 RP-18 F254s, $0.25 \mathrm{~mm}$ ) using 3:4:3 $\mathrm{CH}_{3} \mathrm{CN}: \mathrm{MeOH}: \mathrm{H}_{2} \mathrm{O}$ as eluent (Rf of HA: 0.3). The compounds were detected on TLC plates using UV light ( 254 or $366 \mathrm{~nm}$ ) and/or by spraying the plates with $5 \%(v / v) \mathrm{H}_{2} \mathrm{SO}_{4}$ in EtOH followed by heating at $110{ }^{\circ} \mathrm{C}$ for $10 \mathrm{~min}$. NMR data: see Table 1. LC-MS fragmentation patterns of iso-HA and HA: $\mathrm{HA}:[\mathrm{M}+\mathrm{H}]^{+}=366.2 ;\left[\mathrm{M}+\mathrm{H}-\mathrm{H}_{2} \mathrm{O}\right]^{+}=348.2 ;\left[\mathrm{M}+\mathrm{H}-\mathrm{HCO}_{2} \mathrm{H}\right]^{+}=320.2 ;\left[\mathrm{M}+\mathrm{H}-\mathrm{HCO}_{2} \mathrm{H}-\right.$ $\left.\mathrm{CH}_{3}-\mathrm{CH}_{2}-\mathrm{CH}_{2}-\mathrm{CH}=\mathrm{CH}-\mathrm{CH}=\mathrm{CH}_{2}\right]^{+}=224.1 ; \quad\left[\mathrm{M}+2 \mathrm{H}-\mathrm{HCO}_{2} \mathrm{H}-\left(\mathrm{CH}_{3}-\mathrm{CH}_{2}-\mathrm{CH}_{2}-\mathrm{CH}=\mathrm{CH}-\mathrm{CH}=\mathrm{CH}-\mathrm{CH}-\right.\right.$ $\left.\mathrm{OH})-\left(\mathrm{CH}_{3}-\mathrm{CH}-\mathrm{CH}_{3}\right)-\mathrm{CH}_{3}\right]^{+}=138.0 ;$ iso-HA $[\mathrm{M}+\mathrm{H}]^{+}=366.2 ;\left[\mathrm{M}+\mathrm{H}-\mathrm{HCO}_{2} \mathrm{H}\right]^{+}=320.2 ;[\mathrm{M}+\mathrm{H}-$ $\left.\mathrm{HCO}_{2} \mathrm{H}-\mathrm{CH}_{3}-\mathrm{CH}_{2}-\mathrm{CH}_{2}-\mathrm{CH}=\mathrm{CH}-\mathrm{CH}=\mathrm{CH}_{2}\right]^{+}=224.1 ; \quad\left[\mathrm{M}+\mathrm{H}-\mathrm{HCO}_{2} \mathrm{H}-\mathrm{CH}_{3}-\mathrm{CH}_{2}-\mathrm{CH}_{2}-\mathrm{CH}=\mathrm{CH}-\mathrm{CH}=\mathrm{CH}_{2}\right]^{+}$ = 224.1; $\left[\mathrm{M}+2 \mathrm{H}-\mathrm{HCO}_{2} \mathrm{H}-\left(\mathrm{CH}_{3}-\mathrm{CH}_{2}-\mathrm{CH}_{2}-\mathrm{CH}=\mathrm{CH}-\mathrm{CH}=\mathrm{CH}-\mathrm{CH}-\mathrm{OH}\right)-\left(\mathrm{CH}_{3}-\mathrm{CH}-\mathrm{CH}_{3}\right)-\mathrm{CH}_{3}\right]^{+}=138.0$.

\subsection{Antifungal Assay}

Iso HA was tested against $R$. solani, S. sclerotiorum, $P$. ultimum and B. cinerea to evaluate its antifungal properties. Pathogen plugs (5-mm diameter) from growing edges of colonies were placed at the centre of Petri dishes containing PDA. Iso HA was assayed starting from a $10^{-2} \mathrm{M}$ water solution. The pathogen growth was measured daily as colony diameter for ten days. Each treatment consisted of three replicates and the experiment was repeated twice.

\subsection{In Vitro Plant Growth Promotion}

Seeds of tomato (Solanum lycopersicum cv. San Marzano) were sterilized with 1\% sodium hypochlorite for $5 \mathrm{~min}$, then rinsed 3 times with sterile distilled water. The seeds were allowed to germinate in Petri dishes (150 mm diameter) containing Murashighe \& Skoog (MS) culture medium, $1 \%$ agar and $1 \%$ sucrose. HA and iso HA water dilutions $\left(10^{-5}, 10^{-6}, 10^{-7}, 10^{-8}\right.$ and $\left.10^{-9} \mathrm{M}\right)$ were added separately into the substrate. Six tomato seeds were placed in each Petri dish and three replicates were tested for each salt medium concentration. After germination, the plates were incubated in a growth chamber $\left(25^{\circ} \mathrm{C}, 16 \mathrm{~h}\right.$ of photoperiod). The effect of the treatments was evaluated by measuring the percent of seed germination and the length of roots and stems every $24 \mathrm{~h}$ for 7 days. The experiment was repeated three times.

\subsection{Plant Growth Promotion and Induction of Resistance}

Fifteen days-old tomato seedlings cv. San Marzano were transplanted in $14 \mathrm{~cm}$ pots containing sterilized soil and incubated in a growth chamber $\left(25^{\circ} \mathrm{C}, 16 \mathrm{~h}\right.$ photoperiod). Each plant was treated, on alternate days, by drenching with aqueous solutions of iso HA at three different concentrations $\left(10^{-5}, 10^{-6}\right.$, and $\left.10^{-7} \mathrm{M}\right)$. Each treatment consisted of five replicates and water treated plants were used as control. The plant growth was measured after four weeks in terms of stem length. Furthermore the metabolite ability to induce systemic disease resistance against $B$. cinerea was determined. Three leaves of each stage were infected with $10 \mu \mathrm{L}$ of a pathogen spore suspension $\left(1 \times 10^{5} \mathrm{spore} / \mathrm{mL}\right)$ in germination buffer (PDB 1/5 strength). The incidence of the disease was evaluated by measuring, up to $72 \mathrm{~h}$ post-infection, the necrotic area $\left(\mathrm{mm}^{2}\right)$ on infected leaves as compared to water-treated samples. 
The experiment was repeated twice and data were combined since statistical analysis determined homogeneity of variance $(p \leq 0.05)$.

\subsection{Production of HA and Iso HA in Presence of Plant Tissue}

The production of HA and iso HA by T. harzianum in liquid cultures amended with plant tissue was evaluated. Tomato seedlings (Solanum lycopersicum cv. San Marzano), 15 day-old, were harvested, surface sterilised with sodium hypochlorite $1 \%$ solution, homogenized and added to the substrate (PDB, 1/5 strenght PDB or salt medium $+1 \%$ glucose) at a concentration of $10 \mathrm{~g} \mathrm{~L}^{-1}$. Four $7 \mathrm{~mm}$ diameter plugs of $T$. harzianum, obtained from actively growing margins of PDA cultures, were inoculated to $500 \mathrm{~mL}$ conical flasks containing $100 \mathrm{~mL}$ of medium. Culture broths of $T$. harzianum without amendment with plant were used as controls. The stationary cultures were incubated for $10,20,30$ and 40 days at $25^{\circ} \mathrm{C}$ and then filtered under vacuum. The filtered broths $(0.2 \mu \mathrm{m})$ were subjected to HPLC/DAD analysis for the quantification of metabolites. Each treatment consisted of four replicates and the experiment was repeated twice. Data from the experiments were combined since statistical analysis determined homogeneity of variance $(p \leq 0.05)$.

\section{Conclusions}

The results reported in this work indicated that HA and the new secondary metabolite iso HA are involved in Trichoderma - plant interactions and can be useful for agricultural and non-agricultural applications [20]. The identification of molecules with such biological activities can support the development of new biopesticides and biofertilisers based on fungal compounds as active ingredients, which represent an attractive alternative to products containing only living microorganisms.

\section{Acknowledgments}

The authors thank Davide Stellitano for his technical assistance. Work by the authors FV and MR was supported by a dedicated grant from the Italian Ministry of Economy and Finance to the National Research Council for the project "Innovazione e Sviluppo del Mezzogiorno-Conoscenze Integrate per Sostenibilità ed Innovazione del Made in Italy Agroalimentare-Legge n. 191/2009”. Work by the authors FV, MN, RS, RM, SL, AE, SW and ML was supported by the following projects: European Union Seventh Framework Programme (FP7/ 2007-2013) PURE under the grant agreement no 265865; "S.Re.Va.Pr.O.”, “CA.SVI.PR.OLI.”; "MI.P.RE.VEGE.”; PIL; GenePom-Pro PON02_00395_3082360. Work by RM was also supported by POR Campania FSE 2007-2013, Project CARINA “Sicurezza, sostenibilità e competitività nelle produzioni agroalimentari della Campania” CUP B25B09000080007.

\section{Author Contributions}

All authors have contributed substantially to the work. 


\section{Conflicts of Interest}

The authors declare no conflict of interest.

\section{References}

1. Harman, G.E. Myths and dogmas of biocontrol: Changes in perceptions derived from research on Trichoderma harzianum T-22. Plant Dis. 2000, 84, 377-393.

2. Harman, G.E.; Howell, C.R.; Viterbo, A.; Chet, I.; Lorito, M. Trichoderma species-Opportunistic, avirulent plant symbionts. Nat. Rev. Microbiol. 2004, 2, 43-56.

3. Vinale, F.; Sivasithamparam, K.; Ghisalberti, E.L.; Marra, R.; Woo, S.L.; Lorito, M. Trichoderma-plant-pathogen interactions. Soil Biol. Biochem. 2008, 40, 1-10.

4. Hanson, J.R. Natural Products: The Secondary Metabolites; Royal Society of Chemistry: Cambridge, UK, 2003.

5. Dias, D.A.; Urban, S.; Roessner, U. A Historical Overview of Natural Products in Drug Discovery. Metabolites 2012, 2, 303-336.

6. Chiang, Y.; Lee, K.; Sanchez, J.F.; Keller, N.P.; Wang, C.C.C. Unlocking fungal cryptic natural products. Nat. Prod. Commun. 2009, 4, 1505-1510.

7. Keller, N.P.; Turner, G.; Bennett, J.W. Fungal secondary metabolism-From biochemistry to genomics. Nat. Rev. Microbiol. 2005, 3, 937-947.

8. Sivasithamparam, K.; Ghisalberti, E.L. Secondary metabolism in Trichoderma and Gliocladium. In Trichoderma and Gliocladium; Harman, G.E., Kubicek, C.P., Eds.; Taylor and Francis Ltd.: London, UK, 1998; Volume 1, pp. 139-191.

9. Reino, J.L.; Guerrero, R.F.; Hernández-Galán, R.; Collado, I.G. Secondary metabolites from species of the biocontrol agent Trichoderma. Phytochem. Rev. 2008, 7, 89-123.

10. Vinale, F.; Sivasithamparam, K.; Ghisalberti, E.L.; Woo, S.L.; Nigro, M.; Marra, R.; Lombardi, N.; Pascale, A.; Ruocco, M.; Lanzuise, S.; et al. Trichoderma secondary metabolites active on plants and fungal pathogens. Open Mycol. J. 2014, submitted.

11. Vinale, F.; Ghisalberti, E.L.; Sivasithamparam, K.; Marra, R.; Ritieni, A.; Ferracane, R.; Woo, S.L.; Lorito, M. Factors affecting the production of Trichoderma harzianum secondary metabolites during the interaction with different plant pathogens. Lett. Appl. Microbiol. 2009, 48, 705-711.

12. Sawa, R.; Mori, Y.; Iinuma, H.; Naganawa, H.; Hamada, M.; Yoshida, S.; Furutani, H.; Kajimura, Y.; Fuwa, T.; Takeuchi, T. Harzianic acid, a new antimicrobial antibiotic from a fungus. J. Antibiot. 1994, 47, 731-732.

13. Vinale, F.; Flematti, G.; Sivasithamparam, K.; Lorito, M.; Marra, R.; Skelton, B.W.; Ghisalberti, E.L. Harzianic acid, an antifungal and plant growth promoting metabolite from Trichoderma harzianum. J. Nat. Prod. 2009, 72, 2032-2035.

14. Vinale, F.; Nigro, N.; Sivasithamparam, K.; Flematti, G.; Ghisalberti, E.L.; Ruocco, M.; Varlese, R.; Marra, R.; Lanzuise, S.; Eid, A.; et al. Harzianic acid: A novel siderophore from Trichoderma harzianum. FEMS Microbiol. Lett. 2013, 347, 123-129.

15. Vinale, F.; Sivasithamparam, K.; Ghisalberti, E.L.; Ruocco, M.; Woo, S.; Lorito, M. Trichoderma secondary metabolites that affect plant metabolism. Nat. Prod. Commun. 2012, 7, 1545-1550. 
16. Vinale, F.; Sivasithamparam, K.; Ghisalberti, E.L.; Marra, R.; Barbetti, M.J.; Li, H.; Woo, S.L.; Lorito, M. A novel role for Trichoderma secondary metabolites in the interactions with plants. Physiol. Mol. Plant Pathol. 2008, 72, 80-86.

17. Cai, F.; Yu, G.; Wang, P.; Wei, Z.; Fu, L.; Shen, Q.; Chen, W. Harzianolide, a novel plant growth regulator and systemic resistance elicitor from Trichoderma harzianum. Plant Physiol. Biochem. 2013, 73, 106-113.

18. Marfori, E.C.; Kajiyama, S.; Fukusaki, E.; Kobayashi, A. Trichosetin, a novel tetramic acid antibiotic produced in dual culture of Trichoderma harzianum and Catharanthus roseus callus. Z. Naturforsch. 2002, 57c, 465-470.

19. Marfori, E.C.; Kajiyama, S.; Fukusaki, E.; Kobayashi, A. Phytotoxicity of the tetramic acid metabolite trichosetin. Phytochemistry 2003, 62, 715-721.

20. Marco, S.; Rullo, R.; Albino, A.; Masullo, M.; de Vendittis, E.; Amato, M. The thioredoxin system in the dental caries pathogen Streptococcus mutans and the food-industry bacterium Streptococcus thermophilus. Biochimie 2013, 95, 2145-2156.

Sample Availability: Samples of the compounds $\mathbf{1}$ and $\mathbf{2}$ are available from the authors.

(C) 2014 by the authors; licensee MDPI, Basel, Switzerland. This article is an open access article distributed under the terms and conditions of the Creative Commons Attribution license (http://creativecommons.org/licenses/by/3.0/). 